\title{
Penguatan Memahami Kitab Nurul Yaqin Dengan Media Gambar dan Peta
}

\section{Yusuf}

Sekolah Tinggi Agama Islam Darussalam Nganjuk

Email; zusuv.hamidi@gmail.com

\section{Article History:}

Received : 05-08-2020

Revised : 27-08-2020

Accepted : 23-09-2020

\begin{abstract}
The Nurul Yaqin book is one of the yellow books that tell the history of the journey and struggle of the Prophet Muhammad SAW in spreading Islam. In the book, many stories are told about the joys and sorrows of the Prophet and his companions in the mission of spreading Islam. There are also many descriptions of essential and historical events that have become the treasures of Muslims. One of the efforts to connect the chain of the Prophet's struggle is to teach this book again with methods and media that are fun to students. The use of instructional media is expected to help students capture their imagination, increase their enthusiasm, spark their enthusiasm and provoke their creativity in studying historical books. This research is library research with a qualitative research approach. The data collection method uses the documentary study method. The data analysis method used is the content analysis method. The purpose of this study is to help teachers make it easier for students to accept and understand the contents of the Nurul Yaqin book by utilizing learning media in the form of pictures and maps.
\end{abstract}

Keyword : Nurul Yaqin, Learning Media, Pictures and Maps

\section{Pendahuluan}

Dalam sejarah perkembangan pendidikan di pondok pesantren, para pakar berpendapat bahwasanya antara pesantren dan kitab kuning merupakan dua hal yang tidak bisa terpisahkan di samping adanya kiai, santri, asrama, dan masjid, karena kitab kuning merupakan pelajaran yang wajib hukumnya untuk dipelajari bagi semua santri tanpa terkecuali. ${ }^{1}$ Bahkan beberapa peneliti mengategorikan kitab kuning sebagai arkanul ma'had, entitas yang harus ada dalam sebuah pesantren. Tidak hanya itu, pemerintah juga menyinggung akan hal itu mengingat betapa pentingnya keberadaan kitab kuning tersebut, Kementerian Agama melalui PMA No. 13 Tahun 2014 tentang Pendidikan Keagamaan Islam Pasal 5 menjelaskan bahwa "Pesantren wajib memiliki

\footnotetext{
${ }^{1}$ Imam Wahyono, 'Strategi Kiai Dalam Mensukseskan Pembelajaran Nahwu Dan Shorof Di Pondok Pesantren Al-Bidayah Tegalbesar Kaliwates Jember', Tarbiyatuna: Kajian Pendidikan Islam, 3.2 (2019), 121 <https://doi.org/10.29062/tarbiyatuna.v3i2.262>.
} 
unsur-unsur pesantren yang salah satunya adalah pengajian atau kajian kitab kuning atau dirasah islamiyah dengan pola mu'allimin. Pemerintah dalam hal ini Kementerian Agama telah turut serta dalam upaya pengembangan pesantren dalam bentuk dukungan regulasi, bantuan sarana dan prasarana serta kegiatan pengembangan. ${ }^{2}$

Pembelajaran kitab kuning juga merupakan kegiatan pembelajaran terhadap kitabkitab keagamaan berbahasa arab atau berhuruf arab oleh kiai sebagai pengajar kepada para santri dengan metode-metode tertentu untuk tercapainya tujuan yang telah ditetapkan dalam kurikulum. Ada dua esensial tujuan dalam pembelajaran kitab kuning yang diajarkan kepada para santri di pondok pesantren yaitu di samping mempelajari isi kitab, maka secara tidak langsung juga mempelajari bahasa arab sebagai bahasa kitab tersebut. Oleh karenanya dengan mempelajari kitab kuning, seorang santri yang telah menamatkan pembelajaran di pesantren cenderung memiliki pengetahuan bahasa arab. Sehingga ketika santri sudah menyelesaikan belajarnya, disamping mampu untuk memahami isi kitab, sekaligus juga mampu menerapkan bahasa kitab tersebut menjadi bahasanya. $^{3}$

Bahasa Arab merupakan suatu kajian bidang ilmu yang bersifat penting, khususnya bagi umat Islam. Menurut Sulaiman, Bahasa Arab menjadi dasar dalam memahami khazanah kitab-kitab klasik yang merupakan warisan dari para ulama terdahulu yang sebagian besar memuat ajaran-ajaran Islam serta kehidupan. Pemahaman yang salah terhadap bahasa Arab khususnya ilmu gramatikal menyebabkan pemahaman yang menyimpang terhadap kandungan-kandungan al Qur'an dan Hadits. ${ }^{4}$ Inilah makna esensial dari pembelajaran kitab kuning yang berlaku di pesantren, muara nya adalah menangkap pesan yang disampaikan dalam al Qur'an dan hadits.

Sebagaimana disampaikan Azra, kitab kuning pada umumnya dipahami sebagai kitab-kitab keagamaan berbahasa Arab, menggunakan aksara Arab, yang dihasilkan oleh para ulama dan pemikir muslim lainnya di masa lampau, khususnya yang berasal dari timur tengah. ${ }^{5}$ Kitab kuning mempunyai format sendiri yang khas serta berwarna kekuning-kuningan. Kitab-kitab kuning identik dengan kitab pegangan wajib di kalangan pesantren, namun hari ini kitab-kitab kuning juga digunakan oleh berbagai kalangan termasuk di antaranya adalah perguruan tinggi. ${ }^{6}$

Seperti halnya ragam kitab kuning yang populer diajarkan di pesantren, satu kitab dengan genre sejarah yang juga banyak dipelajari yaitu khulasah Nurul Yaqin, sebuah kitab yang dikarang oleh syaikh Umar Yahya Abdul Djabbar, salah seorang ulama Saudi Arabia yang telah menyusun buku-buku muqarrar berbahasa arab untuk santri-santri

\footnotetext{
${ }^{2}$ Wahyono.

${ }^{3}$ Wahyono.

${ }^{4}$ Fityan Fikrut Tamam, Muhamad Afifudin Mustofa, and Muhammad Ulinnuha Alhasani, 'Pengaruh Perlombaan Qiraatul Kutub Mahrojan Arabi Terhadap Motivasi Pembelajaran Qira'ah Dan Nahwu Di Kalangan Mahasiswa JSA UM', in Seminar Nasional Bahasa Arab, 2019, pp. 329-41.

${ }^{5}$ Tamam, Mustofa, and Alhasani.

${ }^{6}$ Tamam, Mustofa, and Alhasani.
} 
pemula. ${ }^{7}$ Ulama' kelahiran Makkah Al Mukarramah tahun $1320 \mathrm{H}$ ini juga masuk ke Madrasah 'Askariyyah (kemiliteran) dan lulusan dari fakultas kemiliteran di masa Syarif Al-Husain. ${ }^{8}$ Misi utama Umar Abdul Djabbar ialah membentengi umat Islam dari para misionaris dan pemikiran-pemikiran menyusup lainnya dalam umat Islam, semacam syirik, bid'ah, khurafat, dan kawan-kawannya yang memang menjamur di Negeri ini. Cita-cita itu akan terwujud dengan sukses dengan menggalakkan pendidikan, disemarakkan kajian-kajian Islam, dan khutbah-khutbah yang berbobot. ${ }^{9}$

Belajar mengajar adalah suatu kegiatan yang bersifat edukatif. Nilai edukatif mewarnai interaksi yang terjadi antar guru dan anak didik. Interaksi yang bersifat edukatif dikarenakan kegiatan belajar mengajar yang dilakukan diarahkan untuk mencapai tujuan tertentu yang telah dirumuskan sebelum pengajaran dilakukan. Guru dengan sadar merencanakan kegiatan pengajaran secara sistematis dengan memanfaatkan segala sesuatu guna kepentingan pengajaran. ${ }^{10}$

Dalam proses pembelajaran, peserta didik tidak hanya berinteraksi dengan tenaga pengajar sebagai salah satu sumber, tetapi mencakup interaksi dengan semua sumber belajar yang memungkinkan dipergunakan untuk mencapai hasil yang diinginkan. Sedangkan pengetahuan dan keterampilan tentang strategi, menganalisis, memilih, dan memanfaatkan sumber belajar oleh tenaga pengajar pada umumnya belum memadai. Maka dengan demikian perlu dijelaskan tentang bagaimana cara tenaga pengajar dan peserta didik memanfaatkan sumber belajar yang ada dalam upaya memperluas wawasan ilmu pengetahuan, sikap, dan keterampilan peserta didik dalam kegiatan pembelajaran, ${ }^{11}$ termasuk dalam hal ini adalah penggunaan media pembelajaran.

Banyak ragam strategi pembelajaran yang dapat diterapkan pada setiap materi pembelajaran. Strategi tersebut dilandasi oleh cara pandang yang dipergunakan oleh guru dalam memandang pembelajaran. ${ }^{12}$ Pada dasarnya penggunaan strategi, gaya, model, metode, teknik, dan taktik dalam proses pembelajaran adalah sebuah upaya bagaimana materi dapat tersampaikan dengan mudah dan baik kepada siswa, hal itu yang mendasari pemberlakuan berbagai terma tersebut dalam dunia pendidikan.

Pemahaman siswa terhadap isi materi yang diajarkan merupakan hasil belajar kognitif yaitu salah satu tujuan pembelajaran yang dicapai, hasil belajar adalah hasil ketercapaian yang diperoleh siswa dalam kegiatan pembelajaran sesuai dengan kriteria acuan tujuan pembelajaran yang ditetapkan. Salah satu indikator hasil belajar yang baik,

${ }^{7}$ Nafi'atun Khasanah, '10 Nilai Pendidikan Karakter Dalam Kitab Khulashah Nurul Yaqin Karya Umar Abdul Djabbar', 2018.

${ }^{8}$ Khasanah.

${ }^{9}$ Khasanah.

${ }^{10}$ Mohammad Asrori, 'Pengertian, Tujuan Dan Ruang Lingkup Strategi Pembelajaran', Madrasah, 5.Januari (2013), $188<$ https://doi.org/10.18860/jt.v6i2.3301>.

${ }^{11}$ Ramli Abdullah, 'Pembelajaran Berbasis Pemanfaatan Sumber Belajar', Jurnal Ilmiah Didaktika, 12.2 (2012), 216-31<https://doi.org/10.22373/jid.v12i2.449>.

${ }^{12}$ Ihin Solihin, 'Strategi Pembelajaran Nahwu Di Pesantren Ciloa Garut Dan Al-Ihsan Bandung', Jurnal AlTsaqafa, 14.Januari (2017), 359-72. 
di mana siswa mampu memahami isi materi yang diajarkan oleh guru. ${ }^{13}$ Sehingga dengan begitu, para siswa atau peserta didik akan termotivasi untuk mempelajari materinya secara lengkap, utuh dan terus-menerus.

Motivasi adalah proses internal yang mengaktifkan, menuntun, dan mempertahankan perilaku dari waktu ke waktu. Ada banyak jenis, intensitas, tujuan, dan arah motivasi yang berbeda-beda. Motivasi untuk belajar sangat berperan penting bagi siswa dan guru. ${ }^{14}$ Dengan motivasi yang penuh, proses pembelajaran akan dapat dengan mudah untuk dilakukan, baik oleh guru maupun siswa itu sendiri.

Metode penulisan yang digunakan adalah studi literatur (library research) dengan berbagai sumber baik buku, jurnal maupun sumber-sumber dari internet. Selain itu, dilakukan studi lapangan serta wawancara dengan narasumber-narasumber yang pernah berkecimpung dalam pembelajaran kitab Nurul Yaqin baik dari Guru maupun santri atau peserta didik sebagai data penunjang. Karena peneliti merupakan key instrument, dalam mengumpulkan data, peneliti harus terjun sendiri ke lapangan secara aktif. Dengan teknik pengumpulan data berupa observasi partisipasi, wawancara, dan dokumentasi. ${ }^{15}$

Rumusan masalah yang hendak dikaji dalam penelitian ini adalah bagaimana penguatan pemahaman isi dari kitab Nurul Yaqin dengan menggunakan media pembelajaran berupa gambar dan peta. Adapun tujuan dari penelitian ini adalah untuk membantu para guru mempermudah peserta didik menerima dan memahami isi dari kitab Nurul Yaqin dengan memanfaatkan media pembelajaran berupa gambar dan peta.

\section{Diskusi dan Pembahasan}

\section{A. Kitab Nurul Yaqin}

1. Kajian tentang Khulashah Nurul Yaqin

Secara ringkas kitab Khulashah Nurul Yaqin merupakan teks pelajaran yang terdiri dari tiga juz. Asal mulanya dari kitab Nur Al-Yaqin fi Sirah Sayyid Al-Mursalin karya Syaikh Muhammad Al-Khudhari Bek, seorang ulama Mesir. Kitab itu kemudian dipangkas dan diringkas menjadi dua Juz tipis beserta ringkasan tiap-tiap topik pelajaran beserta latihan soal mudzakarah para siswa. Sedangkan Juz ketiga dari Khulasah itu sebetulnya ringkasan dari kitab karya Syaikh Muhammad Al-Khudhari Bek, yaitu Itmam Al-Wafa' fi Sirah Al-Khufa' yang berisi tentang biografi perjuangan empat Khulafa' ar-Rasyidin, Abu Bakar, Umar, Ustman, dan Ali. Namun belum diketahui mengapa judulnya tetap Khulasah Nurul Yaqin, padahal lebih tepat apabila diberi judul Khulashah Itmamul Wafa'.16

\section{Metode penyampaian materi Nurul Yaqin}

\footnotetext{
${ }^{13}$ Rifki Afandi, 'Pengembangan Media Pembelajaran Permainan Ular Tangga Untuk Meningkatkan Motivasi Belajar Siswa Dan Hasil Belajar IPS Di Sekolah Dasar', JINoP (Jurnal Inovasi Pembelajaran), 1.1 (2015), 77 <https://doi.org/10.22219/jinop.v1i1.2450>.

${ }^{14}$ Sulihin B Sjukur, 'Pengaruh Blended Learning Terhadap Motivasi Belajar Dan Hasil Belajar Siswa Di Tingkat SMK', Jurnal Pendidikan Vokasi, 2.3 (2013), 368-78 <https://doi.org/10.21831/jpv.v2i3.1043>.

${ }^{15}$ Iman Gunawan, Metode Penelitian Kualitatif, Universitas Negeri Malang, 2016.

${ }^{16}$ Khasanah.
} 
Dalam pembelajaran kitab kuning, mayoritas pesantren di Indonesia menggunakan sistem bandongan, yaitu sebuah sistem pengajaran tradisional pada sekolah agama atau pesantren yang dilakukan dengan cara para santri duduk mengelilingi kiai yang menerangkan pelajaran. Dalam penyampaian model seperti ini memang sangat terkesan monoton, dan lempeng karena hanya bersifat satu arah, yaitu guru ke santri. Sifat takzim dan penuh tawaduk menerima segala hal yang disampaikan oleh sang guru berperan dominan dalam ranah ini, karena kalangan pesantren meyakini hingga kini sistem bandongan merupakan salah satu di antara beberapa sistem andalan pesantren yang banyak menghantarkan para santri nya menuju keberhasilan.

Namun semakin ke sini, sistem bandongan tidak menutup dari perkembangan, terlebih setelah kitab kuning banyak masuk ke kalangan akademik formal, penyampaiannya pun kini semakin bervariasi dan modern, di antaranya adalah dengan pemanfaatan sebuah media pembelajaran. Jadi penyampaian materi tidak hanya bersifat kognitif karena para santri juga dituntut untuk menangkap pesan yang disampaikan, berimajinasi atau bahkan dipraktikkan secara langsung di kelas tersebut.

\section{B. Media Pembelajaran}

\section{Penggunaan Media Pembelajaran}

Kata "Media" berasal dari bahasa latin yang merupakan bentuk jamak dari "medium", secara harfiah berarti perantara atau pengantar. ${ }^{17}$ Media pembelajaran bermanfaat untuk melengkapi, memelihara dan bahkan meningkatkan kualitas dan proses pembelajaran yang sedang berlangsung, penggunaan media dalam pembelajaran akan meningkatkan hasil belajar, meningkatkan aktivitas siswa, meningkatkan motivasi belajar siswa. ${ }^{18}$ Selain itu, media pembelajaran dapat menciptakan pembelajaran menjadi lebih efektif dengan keterlibatan siswa agar terjadi optimalisasi belajar dan menumbuhkan keterampilan dasar serta keterampilan komplek pada siswa. ${ }^{19}$

Guna meningkatkan efektivitas dan efisiensi pembelajaran, hendaknya dikembangkan berbagai model pembelajaran yang kreatif dan inovatif. Hal ini perlu dilakukan agar proses pembelajaran tidak terkesan kurang menarik, monoton dan membosankan sehingga akan menghambat terjadinya transfer of knowledge. Oleh karena itu peran media dalam proses pembelajaran menjadi penting karena akan menjadikan proses pembelajaran tersebut menjadi lebih bervariasi dan tidak membosankan. ${ }^{20}$ Menyikapi hal ini, diperlukan inovasi dan kreasi guru dalam menjalankan dan memandu pembelajaran di kelas. Dalam kenyataannya retensi siswa atau daya tangkap siswa sangat dipengaruhi oleh model aktivitas belajar yang dilakukan guru. Siswa hanya dapat menyerap 5\% bahan pembelajaran apabila aktivitas ceramah

\footnotetext{
${ }^{17}$ Tejo Nurseto, 'Membuat Media Pembelajaran Yang Menarik', Jurnal Ekonomi Dan Pendidikan, 8.1 (2011), 19-35.

${ }^{18}$ Cepi Riana, 'Media Pembelajaran', in Komputer Dan Media Pendidikan Di Sekolah, pp. 1-38.

${ }^{19}$ Riana.

${ }^{20}$ Ali Muhson, 'Pengembangan Media Pembelajaran Berbasis Teknologi Informasi', Jurnal Pendidikan Akuntansi Indonesia, 8.2 (2010), 1-10 <https://doi.org/10.21831/jpai.v8i2.949>.
} 
dilakukan oleh guru dalam membelajarkan siswa. Sedangkan apabila aktivitas belajar dilakukan dengan teman sebaya, daya retensi siswa mencapai $90 \%{ }^{21}$

Dengan media pembelajaran, maka akan didapatkan beberapa manfaat penggunaan media pembelajaran dalam proses kegiatan belajar mengajar, di antaranya:

a. Menyamakan persepsi siswa.

Ketika menerima informasi dan teori dari guru, kebanyakan para santri menangkap dengan modal pengalaman dan ilmu yang mereka miliki, dari sini terkadang informasi yang didapat menjadi sangat beragam, ada yang paham dengan sebenarnya, paham namun tidak sepenuhnya, gagal paham bahkan sampai salah paham. Maka dari itu, perlu adanya penyamaan persepsi di antara para santri atau siswa melalui media pembelajaran.

b. Mengkongkritkan konsep-konsep yang abstrak.

Mayoritas ilmu yang bersifat teori pada saat penyampaian masih bersifat konsep-konsep yang abstrak. Gambaran ini sangat riskan memunculkan dan memancing imajinasi liar mereka. Untuk mengantisipasi agar pikiran mereka tidak mengembang kemana-mana, maka dibutuhkan alat bantu berupa media pembelajaran untuk menyatakan gambaran yang masih bersifat teoritif tersebut.

c. Menghadirkan objek-objek yang terlalu berbahaya atau sukar didapat ke dalam lingkungan belajar.

Dalam proses pembelajaran juga sangat penting diperhatikan tingkat keamanan serta keselamatan dari peserta didik. Jangan sampai materi yang mereka terima dapat membahayakan psikis dan fisik mereka. Guru harus memperhatikan penuh perihal ini agar tidak terjadi hal-hal yang tidak diinginkan. Guru dapat memanfaatkan media pembelajaran untuk menghadirkan objek-objek yang sekira terlalu berbahaya atau sukar didapat ke dalam lingkungan belajar.

d. Menampilkan objek yang terlalu besar atau kecil.

Dalam kegiatan observasi, terkadang pengamatan terhadap obyek yang sebenarnya akan mengalami kesulitan, bisa terlalu besar, kecil, luas, ekstrem dan sebagainya. Maka dalam hal ini, pemanfaatan media pembelajaran menjadi langkah tepat sebagai perangkat bantu untuk memudahkan peserta didik melakukan penelitian.

e. Memperlihatkan gerakan yang terlalu cepat atau lambat. ${ }^{22}$

Sebagaimana poin sebelumnya, pengamatan terhadap objek asli terkadang mengalami kesulitan, termasuk di antaranya adalah jika objek yang dipelajari memiliki gerakan yang cukup cepat atau lambat. Agar hasil dari pengamatan dapat akurat, maka diperlukan seperangkat alat bantu sebagai media pembelajaran di dalam kelas.

f. Menghadirkan peristiwa yang belum pernah mereka alami.

\footnotetext{
${ }^{21}$ Ryan Andriyanto, 'Media Pengenalan Sholat Fardhu Berbasis Android (Studi Kasus: Taman Pendidikan Al Qur'an Masjid Al Moeladi Bantul)', 2017, pp. 1-15.

${ }^{22}$ Nurseto.
} 
Menyampaikan materi yang belum pernah mereka alami tentu tidak mudah, dibutuhkan strategi dan upaya ekstra agar para peserta didik atau santri dapat menangkap gambaran peristiwa tersebut secara emosional. Jika hal ini terjadi, dapat dipastikan para santri dapat menangkap pesan dari apa yang mereka pelajari. Media yang digunakan bisa memakai video, gambar atau animasi yang identik.

g. Menganalogikan kejadian lampau dengan saat ini.

Penyampaian materi sejarah mengandung maksud bahwa para pembelajar dapat mengambil pelajaran dan menangkap pesan dari model yang memerankan nya. Pelajaran berharga ini dapat dibantu dengan menggunakan seperangkat media pembelajaran agar daya tangkap para santri dapat bekerja maksimal.

\section{Pembelajaran dengan Gambar}

Dalam sistem pembelajaran modern saat ini, siswa tidak hanya berperan sebagai penerima pesan, tapi siswa juga bertindak sebagai komunikator atau penyampai pesan. Dalam kondisi seperti itu, maka terjadi apa yang disebut dengan komunikasi dua arah bahkan komunikasi banyak arah. Dalam komunikasi pembelajaran media pembelajaran sangat dibutuhkan untuk meningkatkan efektifitas pencapaian tujuan pembelajaran. Artinya, proses pembelajaran akan terjadi apabila ada komunikasi antara penerima pesan dengan sumber/penyalur pesan lewat media tersebut. ${ }^{23}$

Para pendidik sering menggunakan gambar sebagai media pembelajaran karena selain lebih praktis dan ekonomis media gambar juga mudah dimengerti. Penggunaan media dalam pembelajaran tidak harus berbasis komputer atau teknologi, melainkan dapat berupa media sederhana. Media gambar merupakan salah satu media visual sederhana yang dapat dijadikan pertimbangan dalam pemilihan media pembelajaran. ${ }^{24}$

Media gambar juga dapat digunakan untuk menyalurkan pesan, merangsang pikiran, perasaan, perhatian, dan kemampuan siswa, sehingga dapat mendorong proses belajar-mengajar. Dengan cara pemanfaatan media gambar tersebut diharapkan dapat mem-bangkitkan kreativitas siswa dan diperoleh pengalaman belajar yang lebih berarti bagi siswa. 25

Menurut Sadiman sebagaimana disampaikan Ngurah Andi Putra, media gambar memiliki beberapa kelebihan di antaranya: 26

a. Sifatnya kongkret dan lebih realistis menunjukkan pokok masalah,

b. Media gambar dapat mengatasi batas ruang dan waktu karena tidak semua benda dapat ditampilkan di kelas dan suatu peristiwa tidak dapat dilihat seperti adanya, dan,

\footnotetext{
${ }^{23}$ Nurseto.

${ }^{24}$ Ihda Nuria Afidah, 'Pengaruh Penerapan Metode Socratic Circles Disertai Media Gambar Terhadap Kemampuan Beroikir Kreatif Siswa', 2012.

${ }^{25}$ Dwi Sulistyorini, 'Peningkatan Keterampilan Menulis Puisi Dengan Media Gambar Pada Siswa Kelas V SDN Sawojajar V Kota Malang', J-Teqip, 1.1 (2010), 12-19.

${ }^{26}$ Ngurah Andi Putra, 'Penggunaan Media Gambar Seri Untuk Meningkatkan Keterampilan Menulis Narasi Pada Mata Pelajaran Bahasa Indonesia Siswa Kelas IV SDN Moahino Kabupaten Morowali', Jurnal Kreatif Tadulako Online, 2.4 (2003), 230-42.
} 
c. Gambar dapat memperjelas suatu masalah.

Namun disamping memiliki kelebihan media gambar juga mempunyai kekurangan yaitu hanya menekankan pada persepsi indera mata dan ukurannya terbatas untuk kelompok besar. Oleh karena itu gambar yang baik digunakan sebagai media pembelajaran harus memenuhi syarat-syarat sebagai berikut;

a. Autentik yaitu gambar harus menunjukkan situasi yang sebenarnya seperti yang dilihat orang.

b. Sederhana yaitu komposisi gambar harus jelas menunjukkan poin pokok dalam gambar.

c. Ukuran relatif yaitu mampu memperbesar dan memperkecil benda/objek yang sebenarnya.

d. Gambar sebaiknya mengandung gerak atau perbuatan.

e. Gambar hendaklah bagus dari segi seni dan sesuai dengan tujuan pembelajaran

3. Pembelajaran dengan Peta

Peta mulai ada dan digunakan manusia sejak manusia melakukan penjelajahan dan penelitian. Walaupun masih dalam bentuk yang sangat sederhana yaitu dalam bentuk sketsa mengenai lokasi suatu tempat. Pada awal abad ke 2 (87 M - $150 \mathrm{M}$ ), Claudius Ptolomaeus mengemukakan mengenai pentingnya peta. Kumpulan dari peta-peta karya Claudius Ptolomaeus dibukukan dan diberi nama "Atlas Ptolomaeus".

Istilah peta dalam bahasa Inggris disebut map. Kata itu berasal dari bahasa Yunani mappa yang berarti taplak atau kain penutup meja. Peta dapat diartikan sebagai gambaran seluruh atau sebagian dari permukaan bumi yang diperkecil pada sebuah bidang datar atau diproyeksikan dalam dua dimensi dengan metode dan perbandingan tertentu. Gambar yang ada pada peta merupakan informasi geografis yang berhubungan dengan bentuk wilayah beserta kenampakan alam atau budaya, misalnya; sungai, gunung, danau, rawa-rawa, laut, batas wilayah, perkampungan, kota, jalan raya dan lainlain).

Pada umumnya, peta digambarkan pada suatu bidang datar dan diperkecil atau diskalakan. Peta adalah gambar, akan tetapi tidak semua gambar adalah peta. Tentunya Anda dapat mengetahui apa yang membedakannya. Penggunaan skala pada peta merupakan perbandingan antara bidang gambar dengan permukaan bumi sebenarnya. Permukaan bumi tidak mungkin digambar sesuai aslinya, sehingga harus diperkecil dengan perbandingan tertentu. Karena peta sebagai gambaran permukaan bumi pada sebuah bidang datar, sedangkan bumi merupakan benda berbentuk bola, maka untuk membuat peta baik sebagian maupun seluruh permukaan bumi harus menggunakan teknik proyeksi tertentu. Ilmu yang mempelajari tentang pengetahuan dan teknik pembuatan peta disebut Kartografi. ${ }^{27}$

Peta menjadi barang yang berharga ketika seseorang ingin mencari sebuah jalan baru atau saat ingin menjelajah tempat yang belum pernah dikunjungi sebelumnya. Peta tersebut bisa berbentuk fisik maupun digital seperti Waze dan Google Maps. Peta sendiri berfungsi sebagai saluran komunikasi antara pembuat dan pengguna peta mengenai

${ }^{27}$ Bagja Waluya, 'Peta, Globe, Dan Atlas'. 
informasi letak atau wilayah geografis. Oleh sebab itu, peta dibuat dengan teknik visualisasi yang tepat agar mudah dipahami serta menciptakan pengertian yang sama antara pembuat dan pengguna peta. ${ }^{28}$

Menurut Hartono, Fungsi peta secara umum adalah:

1. Peta mampu menunjukan posisi atau lokasi relatif (letak suatu tempat dalam hubungannya dengan tempat lain di permukaan bumi)

2. Peta dapat memperlihatkan ukuran (luas dan jarak suatu daerah dapat diukur melalui peta)

3. Peta dapat memperlihatkan bentuk (benua, negara, gunung, dan bentuk- bentuk lainnya) sehingga dimensi nya dapat terlihat

4. Peta sebagai sumber informasi yang mengumpulkan dan menyeleksi data- data dari suatu daerah dan menyajikannya secara terstruktur

\section{Penguatan Pemahaman Kitab Nurul Yaqin dengan Media Gambar dan Peta}

Sebagaimana penjabaran di atas, bahwasanya pembelajaran materi sejarah harus terus dilestarikan termasuk di antaranya adalah pembelajaran kitab Nurul Yaqin. Namun, banyak para pendidik yang hanya sekedar menyampaikan materi saja tanpa diimbangi dengan daya serap peserta didik dalam menangkap pesan yang terkandung di dalamnya. Jika hal ini dibiarkan terus menerus, maka pembelajaran hanya bersifat rutinitas harian dengan hasil yang tidak signifikan.

Maka upaya untuk menguatkan pemahaman terhadap kitab Nurul Yaqin harus digalakkan di antaranya adalah dengan media pembelajaran berupa gambar dan peta. Adapun beberapa hal yang bisa diambil dari penggunaan media tersebut adalah;

\section{Mempermudah menangkap pesan dari isi kitab}

Dalam materi khulasah Nurul Yaqin, banyak disampaikan di dalamnya perjalanan perjuangan Nabi Muhammad Saw., sahabat-sahabatnya dan orangorang yang mengimani akan risalahnya. Juga dituturkan perlawanan dari musuhmusuh beliau yang turut mewarnai dinamika dakwah Nabi dalam menyebarkan agama Islam kala itu.

Dari penuturan bersifat historis ini, hendaknya para peserta didik atau santri dapat menangkap pesan sebagaimana yang disampaikan di dalam kitab. Mereka harus mampu mengambil hikmah dan pelajaran dari apa yang mereka terima agar tahu dan mengerti betapa susah dan sulitnya mendakwakan kebenaran saat itu, kesengsaraan dan perlawanan bertubi-tubi datang silih berganti demi menghalau laju dakwah Nabi menyebarkan risalah kenabian.

Namun terkadang pesan yang disampaikan oleh guru tidak bisa ditangkap oleh siswa dengan berbagai kendala dan faktor yang meliputinya. Maka dengan bantuan gambar dan peta ini. Mereka akan dapat lebih mudah menerima informasi yang disampaikan oleh guru dan juga menyulut imajinasi mereka seolah-olah secara emosional mereka juga turut terbawa atau bergabung di dalamnya.

${ }^{28}$ Boby Irwanto, 'Perancangan Media', Team Project 2017, 2015. 
Misalnya; para guru perlu mencari gambar atau foto gua Hira' versi sekarang saat hendak mengkaji tentang persembunyian Nabi Muhammad Saw. dan sahabat Abu Bakar as Shidiq di gua Hira' dari kejaran musuh yang hendak membunuh mereka berdua. Guru perlu menjelaskan betapa kondisi gua Hira' yang tidak layak huni didukung situasi mencekam menjadi tempat persembunyian manusia mulia saat itu.

Selain itu, untuk memudahkan menangkap pesan yang hendak disampaikan pengarang dalam kitab Nurul Yaqin, ukur pula jarak antara kediaman Nabi dengan gua hira' dengan menggunakan media pembelajaran berupa peta dengan bentuk dan jenis apapun. Dengan demikian para peserta didik juga akan mengerti dan memahami betapa jarak tempuh yang harus dilewati Nabi saat itu penuh dengan kepayahan dan memerlukan tenaga ekstra untuk menuju ke sana. Pesan sejarah dalam peristiwa ini adalah alangkah sulit dan penuh dengan intrik saat penyebaran agama Islam di kala awal kemunculan nya.

\section{Pembelajaran menjadi lebih menyenangkan}

Di dalam proses pembelajaran, paparkan sekalian tentang gambar-gambar sejarah dengan berbagai versi, kondisi lokasi sejarah pada saat itu dan tampilkan sekalian kondisi saat ini. Hal ini akan mampu menghadirkan imajinasi peserta didik menangkap pesan yang hendak disampaikan. Misalkan gambar baik yang mati atau bergerak (video) tentang Khandak. Hadirkan kondisi galian khandak versi lawas dan juga kondisinya saat ini. Selain itu, sesekali juga perlu diputarkan cuplikan film tentang perang khandak saat berkecamuk. Dengan demikian para peserta didik akan mengikuti pembelajaran dengan suka cita dan menyenangkan dan seolah-olah mereka juga turut menyasikan di tengah-tengah pertempuran perang khandak tersebut.

\section{Proses pembelajaran tidak monoton}

Penggunaan media pembelajaran berupa gambar dan peta akan membawa mereka para peserta didik dari pembelajaran yang membosankan. Saat sesi penyampaian materi para guru yang sanggup memaparkan dengan berbagai media akan dapat menjauhkan dari proses KBM yang monoton dan banyak dihindari oleh peserta didik. Pembelajaran yang bervariasi ini tentu akan sangat memudahkan mereka dalam menangkap pesan yang hendak disampaikan.

\section{Siswa menyerap informasi lebih banyak}

Saat materi dibacakan oleh guru dalam satu pertemuan, banyak sekali pesan dan ajaran yang dituturkan di dalamnya, tanpa alat bantu, siswa atau peserta didik hanya akan menerima sedikit informasi dari proses kegiatan tersebut, apalagi tipikal materi sejarah yang tidak banyak disukai oleh para peserta didik. Pada kondisi ini menghadirkan media pembelajaran berupa gambar dan meta menjadi suatu keharusan untuk mengoptimalkan daya serap peserta didik atau santri.

Seperti saat penyampaian materi hijrah Nabi Muhammad beserta rombongan dari Makkah ke Madinah, hal yang perlu diketahui oleh siswa adalah mereka harus benar-benar memahami dan mengetahui objek yang dikaji, sedangkan kebanyakan dari mereka belum mengetahui di mana letak kedua kota tersebut, seberapa jauh 
waktu untuk menempuhnya, bagaimana kondisi jalannya dan apa transportasi yang digunakan kala itu. Maka yang harus dilakukan guru adalah menjelaskan dengan menggunakan alat bantu berupa gambar dan peta. Gambar digunakan untuk menghadirkan imajinasi para peserta didik, dan peta digunakan untuk mengetahui dan mengukur jarak tempuh. Sebagaimana memahami tentang peristiwa hijrah di atas, para peserta didik akan mengerti akan jerih payah dan perjuangan Nabi pada saat hijrah ketika mereka tahu bahwa pada kenyataannya, Dua kota (Makkah dan Madinah) ini berjarak sekitar $490 \mathrm{~km}$. atau jika menggunakan mobil dengan jarak sekitar 457,4 km. Dengan penggunaan media tersebut di atas para peserta akan mampu lebih banyak menangkap pesan dari materi yang diajarkan karena disampaikan dengan mudah dan gamblang.

\section{Kesimpulan}

Dari penjelasan dan gambaran di atas, dapat diambil kesimpulan bahwa untuk mempermudah penguatan pemahaman dalam mengkaji kitab Nurul Yaqin adalah dengan menggunakan media pembelajaran seperti gambar dan peta. Dengan menggunakan alat bantu tersebut, diharapkan peserta didik dapat lebih mudah menerima pesan dan informasi dari isi kitab yang lebih banyak, pembelajaran juga akan berjalan lebih mengasyikkan serta tidak berjalan monoton dan membosankan. Selain itu, kepiawaian guru dalam menjelaskan menggunakan media pembelajaran juga perlu diperhatikan, agar media yang telah disediakan dapat termanfaatkan dengan baik. Keterampilan dalam penguasaan media pembelajaran oleh guru juga turut andil dalam mempercepat pemahaman para peserta didik menangkap pesan lebih banyak dari materi yang disampaikan.

\section{Daftar Rujukan}

Abdullah, Ramli, 'Pembelajaran Berbasis Pemanfaatan Sumber Belajar', Jurnal Ilmiah Didaktika, 12.2 (2012), 216-31 <https://doi.org/10.22373/jid.v12i2.449>

Afandi, Rifki, 'Pengembangan Media Pembelajaran Permainan Ular Tangga Untuk Meningkatkan Motivasi Belajar Siswa Dan Hasil Belajar IPS Di Sekolah Dasar', JINoP $\begin{array}{lllll}\text { (Jurnal Inovasi } & \text { Pembelajaran), } & 1.1 & \text { (2015), } & 77\end{array}$ $<$ https://doi.org/10.22219/jinop.v1i1.2450>

Afidah, Ihda Nuria, 'Pengaruh Penerapan Metode Socratic Circles Disertai Media Gambar Terhadap Kemampuan Beroikir Kreatif Siswa', 2012

Andriyanto, Ryan, 'Media Pengenalan Sholat Fardhu Berbasis Android (Studi Kasus: Taman Pendidikan Al Qur'an Masjid Al Moeladi Bantul)', 2017, pp. 1-15

Asrori, Mohammad, 'Pengertian, Tujuan Dan Ruang Lingkup Strategi Pembelajaran', Madrasah, 5.Januari (2013), 188 <https://doi.org/10.18860/jt.v6i2.3301>

Gunawan, Iman, Metode Penelitian Kualitatif, Universitas Negeri Malang, 2016

Irwanto, Boby, 'Perancangan Media', Team Project 2017, 2015

Khasanah, Nafi'atun, '10 Nilai Pendidikan Karakter Dalam Kitab Khulashah Nurul Yaqin Karya Umar Abdul Djabbar', 2018

Muhson, Ali, 'Pengembangan Media Pembelajaran Berbasis Teknologi Informasi', Jurnal 


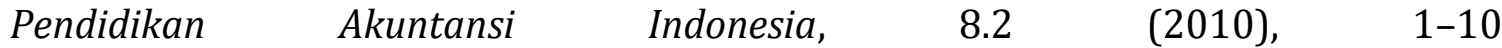
$<$ https://doi.org/10.21831/jpai.v8i2.949>

Nurseto, Tejo, 'Membuat Media Pembelajaran Yang Menarik', Jurnal Ekonomi Dan Pendidikan, 8.1 (2011), 19-35

Putra, Ngurah Andi, 'Penggunaan Media Gambar Seri Untuk Meningkatkan Keterampilan Menulis Narasi Pada Mata Pelajaran Bahasa Indonesia Siswa Kelas IV SDN Moahino Kabupaten Morowali', Jurnal Kreatif Tadulako Online, 2.4 (2003), 230-42

Riana, Cepi, 'Media Pembelajaran', in Komputer Dan Media Pendidikan Di Sekolah, pp. 138

Sjukur, Sulihin B, 'Pengaruh Blended Learning Terhadap Motivasi Belajar Dan Hasil Belajar Siswa Di Tingkat SMK', Jurnal Pendidikan Vokasi, 2.3 (2013), 368-78 $<$ https://doi.org/10.21831/jpv.v2i3.1043>

Solihin, Ihin, 'Strategi Pembelajaran Nahwu Di Pesantren Ciloa Garut Dan Al-Ihsan Bandung', Jurnal Al-Tsaqafa, 14.Januari (2017), 359-72

Sulistyorini, Dwi, 'Peningkatan Keterampilan Menulis Puisi Dengan Media Gambar Pada Siswa Kelas V SDN Sawojajar V Kota Malang', J-Teqip, 1.1 (2010), 12-19

Surahmi, Siti, 'Nilai-Nilai Pendidikan Karakter Dalam Kitab Khulasah Nurul Yaqin', 2021

Tamam, Fityan Fikrut, Muhamad Afifudin Mustofa, and Muhammad Ulinnuha Alhasani, 'Pengaruh Perlombaan Qiraatul Kutub Mahrojan Arabi Terhadap Motivasi Pembelajaran Qira'ah Dan Nahwu Di Kalangan Mahasiswa JSA UM', in Seminar Nasional Bahasa Arab, 2019, pp. 329-41

Wahyono, Imam, 'Strategi Kiai Dalam Mensukseskan Pembelajaran Nahwu Dan Shorof Di Pondok Pesantren Al-Bidayah Tegalbesar Kaliwates Jember', Tarbiyatuna:

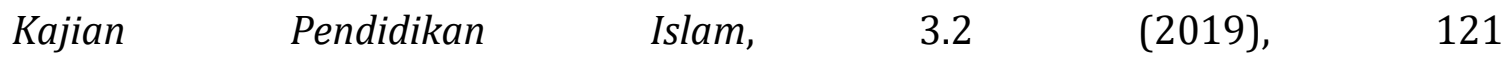
<https://doi.org/10.29062/tarbiyatuna.v3i2.262>

Waluya, Bagja, 'Peta, Globe, Dan Atlas' 